
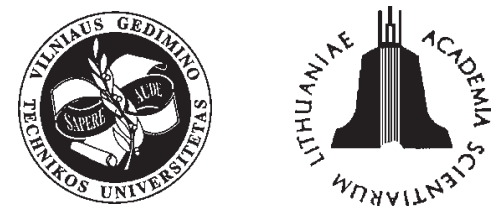

ISSN 1392-3730 print / ISSN 1822-3605 online

JOURNAL OF CIVIL ENGINEERING AND MANAGEMENT

http:/www.jcem.vgtu.lt

2006, Vol XII, No 1, 57-62

\title{
EFFICIENCY OF PUMP OPERATION IN HYDRONIC HEATING AND COOLING SYSTEMS
}

\author{
Per Fahlén, Hendrik Voll, Jüri Naumov \\ Chalmers University of Technology, Building Services Engineering, \\ SE-41296 Gothenburg, Sweden.E-mail: perfahlen@chalmers.se
}

Received 18 April 2005; accepted 30 Nov 2005

\begin{abstract}
Developments in pump technology provide new possibilities of improving both the efficiency and the quality of control of hydronic heating and cooling systems. Improved pump efficiency and direct flow control can substantially reduce the drive power to circulation pumps. Measurements show that a simple VSD (variable speed drive) does not unduly degrade the efficiency of commonly used pumps. An example from a residential heat pump installation indicates possible savings of around $30 \%$ of the total drive energy to the heat pump. Another example illustrates how direct flow control can simplify systems and reduce electric drive power in supply-air conditioning systems.
\end{abstract}

Keywords: control, cooling, efficiency, fan, heating, motor, pump, speed.

\section{Introduction}

Buildings employ numerous small and medium-sized pumps and fans in HVAC systems. Due to the low rated power of the individual components, interest in their efficiency and operation has so far been low. The overall efficiency of the smallest units may be well below $10 \%$ and their numbers and long operating hours result in substantial electric energy use. For instance, in indirect supermarket cooling systems it is not uncommon that the energy for pump operation exceeds the drive energy for refrigeration compressors.

Developments in motor controls provide new possibilities of improving both the efficiency and quality of control. Direct flow control can render superfluous many balancing and control valves of traditional systems. Most of the pressure drop in current systems has been introduced to make the systems controllable. This pressure drop is unnecessary with direct pump control. As a re- sult, pump power may be substantially reduced just by a new control principle. Recent improvements in pump and motor technology can add further savings.

To assist the analysis of pump and fan work, some type of classification is helpful. Table 1 provides an example for the heating side of a small residential heat pump installation (see Results). Depending on the function, requirements will be quite different. Long operating hours at fairly constant capacity puts the focus on efficiency at the design point, whereas short operating hours in a wide capacity range stresses controllability and dynamic range.

\section{Methods}

This work is a pre-study by means of simple measurements and calculations to investigate the possibilities of energy savings through the use of state-of-the-art pump and fan technology in HVAC systems.

Table 1. Operational time, drive power and transported heat for heating and hot water. An example for a small residential ground source heat pump

\begin{tabular}{l|r|r|r|l}
\hline $\begin{array}{l}\text { Function of } \\
\text { pump/fan }\end{array}$ & $\begin{array}{r}\text { Operating } \\
\text { time }[\mathrm{h}]\end{array}$ & $\begin{array}{c}\text { Pumping power } \\
{[\mathrm{W}]}\end{array}$ & Heat $[\mathrm{kW}]$ & \multicolumn{1}{c}{ Comment } \\
\hline $\begin{array}{l}\text { Condenser } \\
\text { flow rate }\end{array}$ & $\begin{array}{r}\text { Approx } \\
3000\end{array}$ & $\begin{array}{l}\text { Theory: } 2-3 \\
\text { Real: } 40-50\end{array}$ & $\begin{array}{r}\text { Approx } \\
4,2\end{array}$ & $\begin{array}{l}\text { Average on-time, av } \\
\text { thermal capacity }\end{array}$ \\
\hline $\begin{array}{l}\text { Heating system } \\
\text { flow rate }\end{array}$ & $\begin{array}{r}\text { Approx } \\
6600\end{array}$ & $\begin{array}{l}\text { Theory: } 2-3 \\
\text { Real: } 40-50\end{array}$ & $0-4,2$ & $\begin{array}{l}\text { Long on-time, low to } \\
\text { middle thermal capacity }\end{array}$ \\
\hline Fan-coil & Approx & $\begin{array}{l}\text { Theory: } 3-5 \\
\text { Real: } 60-80\end{array}$ & $0-4,2$ & $\begin{array}{l}\text { Long on-time, low to } \\
\text { middle thermal capacity }\end{array}$ \\
\hline $\begin{array}{l}\text { SHW heat } \\
\text { exchanger }\end{array}$ & $\begin{array}{r}\text { Approx } \\
600\end{array}$ & $\begin{array}{l}\text { Theory: } 1-3 \\
\text { Real: } 30-40\end{array}$ & $0-25$ & $\begin{array}{l}\text { Short on-time, low to } \\
\text { high thermal capacity }\end{array}$ \\
\hline
\end{tabular}




\subsection{Power and energy use for pump operation}

Pump duty can be classified in terms of the pump power in relation to the heat capacity flow rate (cf Table 1). Applications:

1) low power and long operating hours, eg heating and cooling systems;

2) high power and short operating hours, eg direct sanitary water heating systems, and

3) average power and average operating hours, eg condenser and evaporator flows of refrigerating equipment and heat pump installations.

The focus will be on opportunities in the first category with discussions on alternative solutions for systems with heating and cooling coils.

The principle discussion is valid for both pumps and fans but we will only deal with pumps explicitly. The motor work depends on a number of units and their individual power input and operating hours according to

$$
W_{e, p}=\sum_{i=1}^{i=n} \dot{W}_{e, p}^{i} \cdot \tau_{o n}^{i} \quad[\mathrm{~J}] \text { or }[\mathrm{kWh}],
$$

where $W_{e, p}=$ total energy for pump operation, $\dot{W}_{e, p}^{i}=$ power input to pump No $i$ and $\tau_{o n}^{i}=$ operating hours of pump No $i$. The power input of each pump is decided by functional requirements on flow rate, resulting pressure drops in the system, and the overall efficiency of the pump according to

$$
\dot{W}_{e, p}=\frac{\dot{V} \cdot \Delta p}{\eta_{p}}[\mathrm{~W}] .
$$

Eqs 1 and 2 indicate that the drive energy can be reduced through the following actions (individually or in combinations): 1) reduce the number of pumps, 2) the operating hours, 3) the flow rates and pressure drops, 4) increase the efficiencies. Alternative system layouts, control strategies, and the selection of coils will influence the first three items. New pump motor controls enhance the possibilities of more efficient control. Improved hydraulic design and more efficient motors will address the final savings opportunity.

\subsection{Possibilities for control of the thermal capacity of air-coils}

Trüschel [1] and others have studied the performance of hydronic systems but the basics of their functioning are rarely pointed out. In hydronic systems, the pump flow has two major tasks: to transport heat and to promote heat transfer in the terminal unit. By means of the $\varepsilon$-NTU method [2] and specified inlet air and water temperatures to the coil $\left(t_{a 1}\right.$ and $\left.t_{w 1}\right)$, the thermal capacity can be calculated as

$$
\dot{Q}_{a c}=\varepsilon \cdot \dot{C}_{\min } \cdot\left(t_{w 1}-t_{a 1}\right)[\mathrm{W}]
$$

Applying logarithmic differentiation to $\mathrm{Eq} \mathrm{3,} \mathrm{the}$ sensitivity of the thermal capacity to changes in the respective parameters can be estimated

$$
\frac{\Delta \dot{Q}_{a c}}{\dot{Q}_{a c}}=\frac{\Delta \varepsilon}{\varepsilon}+\frac{\Delta \dot{C}_{\min }}{\dot{C}_{\min }}+\frac{\Delta\left(t_{w 1}-t_{a 1}\right)}{\left(t_{w 1}-t_{a 1}\right)}[-],
$$

$\varepsilon=\varepsilon\left(R, N_{t u}\right)-$ the coil effectiveness, $R=\dot{C}_{\min } / \dot{C}_{\max }-$ the ratio of the minimum and maximum heat capacity flow rates, and $N_{t u}=U \cdot A / \dot{C}_{\text {min }}$. In high-flow systems $\dot{C}_{a} \leq \dot{C}_{w}$, then $\dot{C}_{\min }=\dot{V}_{a} \cdot \rho_{a} \cdot c_{p, a}$. This type of sensitivity analysis is helpful in formulating linearised transfer functions in control system design. It is straightforward also to differentiate $\varepsilon=\varepsilon\left(\dot{C}_{a}, \dot{C}_{w}\right)$.

Eq 4 indicates that the principle possibilities of controlling the thermal capacity relate to $\dot{C}_{\max }$ (via $R$ and $\left.N_{t u}\right), \dot{C}_{\min }$ and $t_{w 1}\left(t_{a 1}\right.$ is the indoor or outdoor air temperature assumed to be constant). In radiator systems, the airflow cannot be controlled directly and will be affected by $\theta_{\mathrm{ac}}\left(\dot{C}_{a}=\dot{C}_{a}\left(t_{w 1}, t_{a 1}\right)\right)$. In fan-coils, supplyair heaters and other forced convection units, variable airflow is a very direct but not always used control method. However, if we look only at control on the waterside, then obviously two possibilities remain: flow rate and temperature control (individually or in combination).

Eq 4 clearly shows the direct influence of supply water temperature on thermal capacity. Flow control affects the thermal efficiency by changing both $N_{t u}$ and $R$. In a high-flow design, a change in the water flow of an air-coil normally has a small influence on $N_{t u}$ but a direct influence on $R$. Also, Fig 1 indicates that as long as $N_{t u}$ is not affected, then the change in flow must be very large to have an effect on efficiency and hence on capacity $\left(\dot{C}_{w}=\infty\right.$ to $\dot{C}_{a} \Rightarrow 20-25 \%$ ).

In a high-flow system $\left(\theta_{w}<20 \mathrm{~K}\right), \dot{C}_{a} \leq \dot{C}_{w}$ and hence water flow has a relatively small influence on capacity. A typical design value is $R=1,5-2$. This means that $\dot{C}_{w}$ has to decrease to around half its design value to take over the direct influence on capacity from $\dot{C}_{a}$ and $t_{w 1}$. In systems with variable airflow, the thermal capacity becomes less controllable by means of the water flow as the airflow decreases. Then water flow should be also adjusted to maintain control and to avoid unnecessary pumping. In a low-flow system $\left(\theta_{w}>20 \mathrm{~K}\right)$, we have $\dot{C}_{w} \leq \dot{C}_{a}$ already from the start and then control of the water flow becomes a very direct way of adjusting coil capacity.

\subsection{Traditional solutions and new possibilities}

The pumping power in relation to transferred thermal capacity depends on system design and component selection. To maintain constant heat transfer characteristics, a design with a constant flow rate and variable temperature according to Fig 2 has been common. This design involves a number of valves, which introduce pressure drops, and maintain the same pumping power irrespective of the thermal capacity. 


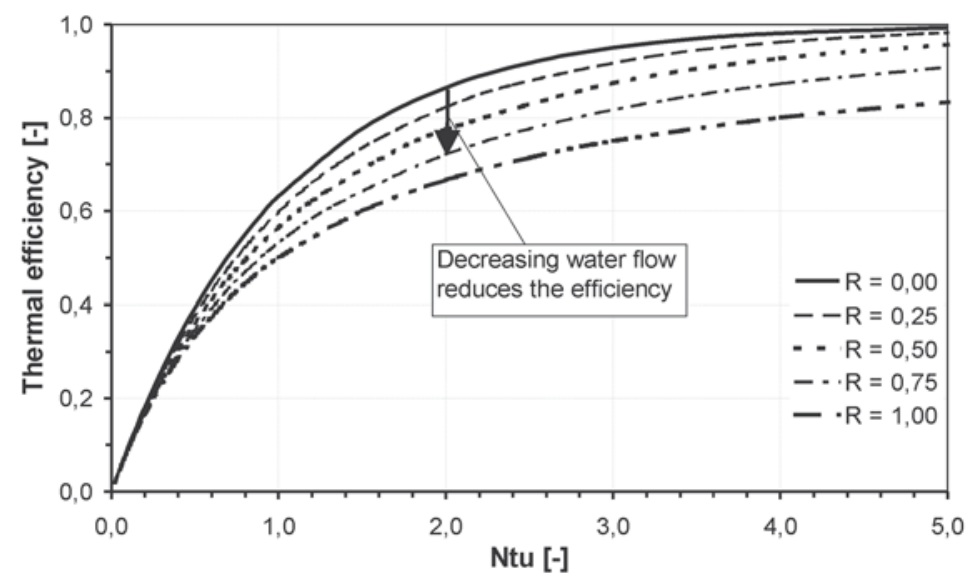

Fig 1. Thermal efficiency of a counter flow heat exchanger as a function of the number of transfer units with the heat capacity flow rate ratio as a parameter

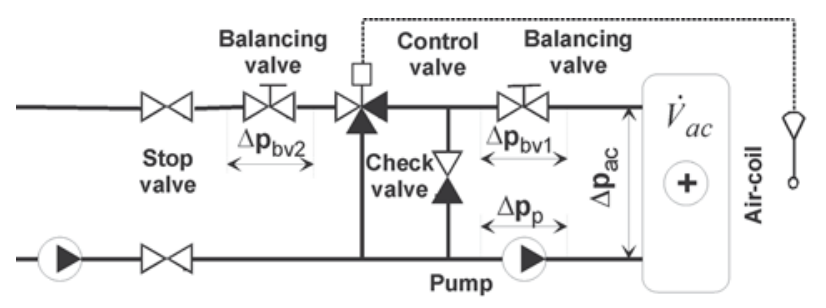

Fig 2. Common Swedish connection for air heaters and coolers (constant supply flow rate and constant coil flow rate)

In this type of variable temperature control, there will be a dead time related to the flushing time of the coil $\left(\tau_{d}=V_{w, a c} / \dot{V}_{w, a c}\right)$. The flushing time can be in the range 10-30 s. In systems with large amplification (a small P-band) and rapid sensor response, this may lead to problems with control stability.

A simpler design, which has become increasingly popular, uses a variable flow according to Fig 3. In this case, there is only one balancing valve at the air-coil, so the pressure drop under design conditions may be smaller than in Fig 2 and furthermore it will decrease as the thermal capacity is turned down.

In traditional designs (Figs 2, 3), valves control the flow rate through the coil and the system. To ascertain

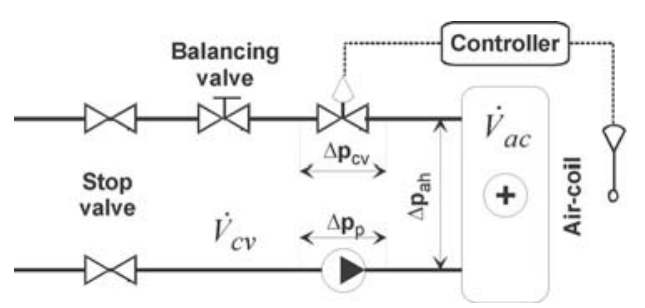

Fig 3. Direct connection with variable coil flow rate: valve control valve authority a rule of thumb is to design the pressure drop of the control valve to be at least $50 \%$ of the total pressure drop in the circuit and this ratio will increase as capacity is decreased. Hence, the biggest pressure drop in the circuit is the one introduced by the designer to make the system controllable. In times when low pressure drops and energy efficiency is stressed, this is contrary to what is desired.

Fortunately, modern pump and fan technology with the state-of-the-art motor control offers new system design possibilities and improved component efficiency. With direct flow control and a Variable Speed Drive (VSD) according to Fig 4, one can dispose of the control and balancing valves and their associated pressure drops. There are both advantages and disadvantages with the VSD solution. Advantages include reduced pump energy, simple design, few components, simple control and improved stability, and less flow-induced noise. Disadvantages involve EMI and, possibly, new design and dimensioning of air-coil installations.

\section{Results}

The energy saving opportunities will be illustrated by results of simple laboratory measurements on pump efficiency and control, field measurements on a residential heat pump and calculations on three typical connections of air heaters and coolers.

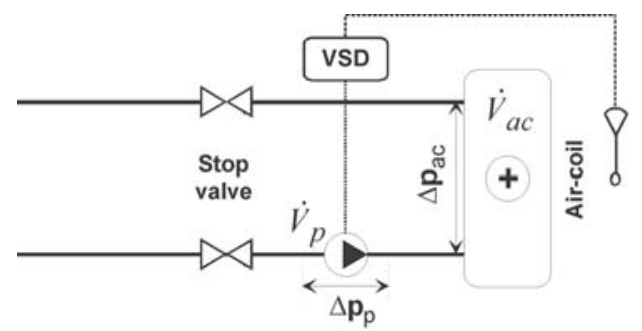

Fig 4. Direct connection with variable coil flow rate: pump control 


\subsection{Pump efficiency and control}

Laboratory measurements on a number of small circulation pumps indicate that efficiencies are quite low, often less than $10 \%$. Fig 5 illustrates how the efficiency varies with flow rate for a pump with three fixed speeds. The diagram gives the manufacturer's values and some measured values. Measured flows were achieved both by means of throttling at a fixed speed and by means of a simple dimmer-type motor control and variable speed. The effect on efficiency of the dimmer is only marginal. This provides the same flow at a reduced head and hence the drive power will be reduced.

Even though the efficiency of commonly installed circulation pumps is disappointing, manufacturers have developed much better units. Already in 1999, Nipkow [3] reported overall efficiencies of the order of $40 \%$. This can reduce the input of the smallest available pumps from 40 to $10 \mathrm{~W}$, which is much closer to the theoretical need of 2-4 W of many applications (Table 1).

\subsection{Field measurements on a residential heat pump}

Fahlén [4] has pointed out the relative importance of inefficient pump and fan installations on the COP of residential heat pumps. Table 2 gives the resulting drive energies to pumps and a hydronic fan-coil for heat distribution in relation to the drive energy to the compres- sor. Parasitic drive energies, ie those small powers with long operating hours that are often neglected, amount to $38 \%$. If the heating water pump had not been manually shut-off during the summer, this figure would have been $50 \%$, thus reducing the $S P F$ by a factor two. Using the state-of-the-art technology could reduce the parasitic ratio to 0,08 !

\subsection{Pumping power for alternative connections of air heaters and coolers}

To illustrate the effect on pumping power by the system configuration and control method, the theoretical power was calculated for the three alternatives in Figs 2 and 3 ( $\dot{W}_{e p, a c}$ is the pump work for the air-coil per se). In case 1 the pumping power is constant and given by

$$
\begin{gathered}
\dot{W}_{e p}=\frac{\dot{V}_{w} \cdot\left(\Delta p_{b v 1}+\Delta p_{c v 1}+\Delta p_{a c}\right)}{\eta_{p 1}}+ \\
+\frac{\dot{V}_{w} \cdot\left(\Delta p_{b v 2}+\Delta p_{c v 2}\right)}{\eta_{p 2}}>2 \cdot \dot{W}_{e p, a c} .
\end{gathered}
$$

In case 2, pump work will drop with capacity according to

$$
\dot{W}_{e p}=\frac{\dot{V}_{w} \cdot\left(\Delta p_{c v}+\Delta p_{a c}\right)}{\eta_{p}} \leq 2 \cdot \dot{W}_{e p, a c} \quad[\mathrm{~W}] .
$$

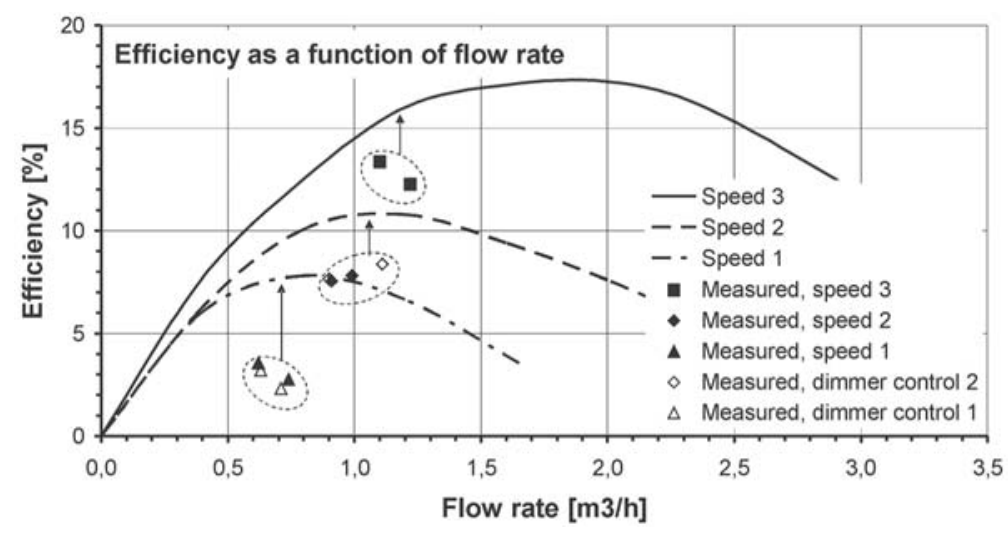

Fig 5. Efficiency as a function of flow rate with and without 'dimmer' control for a typical, small circulation pump

\begin{tabular}{|c|c|c|c|c|c|}
\hline \multirow[t]{2}{*}{ Function } & \multirow{2}{*}{$\frac{\text { Power }}{[\mathrm{W}]}$} & \multicolumn{2}{|c|}{ Operating time } & \multirow{2}{*}{$\begin{array}{c}\text { Drive energy } \\
\qquad[\mathrm{kWh}]\end{array}$} & \multirow{2}{*}{$\begin{array}{c}\text { Parasitic ratio } \\
{[-]}\end{array}$} \\
\hline & & hours [h] & relative [-] & & \\
\hline Compressor & 1055 & 2995 & 0,34 & 3159 & 1,00 \\
\hline Brine pump & 96 & 2995 & 0,34 & 288 & 0,09 \\
\hline Heating water pump & 48 & 6595 & 0,75 & 317 & 0,10 \\
\hline Fan-coil & 61 & 6595 & 0,75 & 402 & 0,13 \\
\hline Recharging pump & 37 & 5498 & 0,63 & 203 & 0,06 \\
\hline Parasitic sum & 242 & & & 1210 & 0,38 \\
\hline Total sum & 1297 & & & 4369 & \\
\hline
\end{tabular}

Table 2. Results from measurements of a heat pump in 2002. The parasitic ratio is the energy to pumps and fans divided by the energy to the compressor 
And finally, in case 3, the starting value will be half that of 1 and 2 and it will drop more quickly than in case 2, where the valve resistance increases with a reduction in capacity:

$$
\dot{W}_{e p}=\frac{\dot{V}_{w} \cdot \Delta p_{a c}}{\eta_{p}} \leq \dot{W}_{e p, a c} \quad[\mathrm{~W}]
$$

\section{Discussion}

Small pumps and fans operate in large numbers and with long operating hours. Upgrading these units to stateof-the-art efficiency and control can drastically reduce the electric drive energy. For instance, in Sweden the possible savings on small pumps alone are of the same order of magnitude as the total Swedish supply of windgenerated electric energy. The savings alternative has no visible impact on the environment and a much lower cost. A practical example [4] shows that state-of-the-art pump technology in a small heat pump installation can reduce parasitic drive energy from $30-40 \%$ to less than $10 \%$.

In hydronic systems, changing the layout from traditional shunt-circulation with constant flow to direct flow control can drastically reduce pump work and at the same time improve control. However, the system must be suitably designed to ascertain controllability and thermal capacity. At low capacity, the flow regime may become laminar with a sudden drop in output. However, it is possible to design very efficient coils operating only with laminar flow [5].

One way to ascertain the control authority in a system with direct flow control is to design the coil with balanced heat capacity flow rates at maximum capacity. Then, as demand goes down and capacity is accordingly reduced, the liquid-side heat capacity flow rate will be the minimum and hence decisive for the heat transfer capacity (Eq 2). Higher water flows will contribute little to the heat transfer performance and thus be wasteful. Even so, as efficiency drops quickly off the design point, it is recommended to design with a slightly overbalanced water flow (a common principle for liquid-coupled heat recovery systems).

In case of a VAV system, water flows in heaters and coolers should be reduced in relation to the air volume. This will maintain control and avoid unnecessary pump work. Furthermore, in systems with intelligent control [6] it is possible to automatically optimise media flows on both sides of the heat exchanger with given restrictions.

This article is based on a presentation 2004 at the REHVA conference „Energy for Buildings” in Vilnius, Lithuania [7].

\section{References}

1. Trüschel, A. Hydronic heating systems - The effect of design on system sensitivity. Chalmers University of Technology, Building Services Engineering, D62:2002, Sweden.
2. Kays, W. M. and London, A. L. Compact heat exchangers. McGraw-Hill 1984. New York, USA.

3. Nipkow, J. and Meyer, W. Innovative pump developments in Switzerland. ITW-Wilo, 1999.

4. Fahlén, P. Heat pumps in hydronic heating systems - Efficient solutions for heating and hot water in retrofitting houses with direct-acting electric heating (in Swedish). Statens Energimyndighet, eff-Sys H23, 2004. Eskilstuna, Sweden.

5. Haglund-Stignor, C.; Fahlén, P.; Sundén, B. and Eriksson D. Optimal operation of cooling-coils for display cabinets in secondary-loop refrigeration systems. 21 st Intern Congress of Refrigeration, IIR, 2003-08-17-22. Washington, USA.

6. Karlsson, F. and Fahlén, P. Energy saving potential of capacity controlled brine-to-water heat pumps. 21st Intern Congress of Refrigeration, IIR, 2003, USA.

7. Fahlén, P. Voll, H. and Naumov, J. Efficiency of pump operation in hydronic heating and cooling systems. In: REHVA, Conference „Energy for Buildings”, 7-8 Oct 2004. Vilnius: Technika, 2004, p. 250-258.

\section{Nomenclature}

\section{Latin symbols}

A area, $\mathrm{m}^{2}$

$c \quad$ specific heat capacity, $\mathrm{J} / \mathrm{kg} / \mathrm{K}$

$C$ heat capacity, $\mathrm{J} / \mathrm{kg}$

$\dot{C} \quad$ heat capacity flow rate, $\mathrm{W} / \mathrm{K}$

COP coefficient of performance, $\mathrm{W} / \mathrm{W}$

$N \quad$ number

$p \quad$ pressure, $\mathrm{Pa}$

$Q \quad$ thermal energy (heat), $\mathrm{J}$

$\dot{Q} \quad$ thermal capacity, W

$t \quad$ Celsius temperature, ${ }^{\circ} \mathrm{C}$

$T \quad$ absolute temperature, $\mathrm{K}$

$U$ thermal transmittance, $\mathrm{W} / \mathrm{m}^{2} / \mathrm{K}$

$W \quad$ work (mechanical, electric), J

$\dot{W} \quad$ power, $\mathrm{W}$

\section{Greek symbols}

$\alpha \quad$ heat transfer coefficient, $\mathrm{W} / \mathrm{m}^{2} / \mathrm{K}$

$\Delta p \quad$ pressure difference, $\mathrm{Pa}$

$\varepsilon \quad$ heat exchanger efficiency

$\eta \quad$ efficiency

$\theta \quad$ temperature difference, $\mathrm{K}$

$\tau \quad$ time, $\mathrm{s}$ 


\section{Subscripts and superscripts}

a

$\mathrm{ac}$

by

CV

d

$\mathrm{e}$

i

on

$\mathrm{p}$

tu air

air-coil

balancing valve

control valve

dead (time)

electric

running index

on (unit in operation)

pump

transfer units
W

1

2

outlet water

inlet
CAV

EMI

NTU

SHW

SPF

VSD
Abbreviations

Constant Air Volume

Electro Magnetic Interference

Number of Transfer Units

Sanitary Hot Water

Seasonal Performance Factor

Variable Speed Drive

\section{SIURBLIŲ EFEKTYVUMAS ŠILDYMO IR AUŠINIMO SISTEMOSE}

\section{P. Fahlen, H. Voll, J. Naumov}

\section{Santrauka}

Spartus technologijų vystymasis atveria naujų galimybių didinti siurblių efektyvumą bei užtikrina kokybišką reguliavimą šildymo ir vėsinimo sistemose. Padideję̧s siurblių efektyvumas ir tiesioginis srauto valdymas gali gerokai sumažinti cirkuliacinių siurblių energijos poreikị. Matavimai rodo, kad kintamojo greičio naudojimas nemažina siurblių efektyvumo. Pateikiamas pavyzdys iš gyvenamajame name instaliuoto šilumos siurblio sistemos rodo galimybę sutaupyti $30 \%$ energijos. Kitas pavyzdys rodo, kaip tiesioginis srauto valdymas gali supaprastinti sistemą ir sumažinti elektros energijos poreikius oro kondicionavimo sistemose.

Raktiniai žodžiai: valdymas, aušinimas, efektyvumas, ventiliatorius, šildymas, variklis, siurblys, greitis

Per FAHLÉN. Head of Building Services Engineering at Chalmers University of Technology, Gothenburg, Sweden. Research areas: indoor climate, ventilation and heat recovery, heating and cooling systems, heat pumps and refrigeration, control systems, and measuring techniques. Publications: 25 reviewed articles, 70 books/reports, 60 popular articles, 110 conference presentations.

Hendrik VOLL. PhD student with a scholarship at Building Services Engineering, Chalmers University of Technology. Research areas: heating and cooling demand in office buildings, in particular the effects of insolation.

Jüri NAUMOV. PhD student with a scholarship at Building Services Engineering, Chalmers University of Technology. Research areas: heating and cooling demand of buildings; in particular use of ground-source heat pumps for combined heating and cooling, including seasonal storage and free-cooling techniques. 